\title{
Does Brand Image Certainly Mediate Relationships between $e$ - WOM and Purchase Intention? A Case Study of Samsung Smartphone Marketing in Papua
}

\author{
Ivana $\mathbf{W}$. \\ Faculty of Economic and Business, \\ Cenderawasih University, Papua, Indonesia \\ Uturestantix \\ Faculty of Economic and Business, \\ Cenderawasih University, Papua, Indonesia
}

\begin{abstract}
The purpose of this study is to investigate the effect and also interrelationship between the variables of e-WOM, brand image, and purchase intention of Samsung smartphones in Jayapura. 100 students from various colleges that spread across Jayapura city were sampled in this research. A quantitative approach with deduction and causal hypothesis testing was employed in this project. Cross-sectional method was also conducted in this study to design the survey with research time dimension. Sampling process of respondents were done using non-probability sampling with purposive sampling technique, by judgment sampling. To analyse data and test the hypotheses, multiple regression and hierarchical regression analyses were applied utilising statistical software, SPSSVer.21.0. The results of its hypothesis testing prove that eWOM has a significant positive effect on brand image and purchase intention, while the brand image itself promotes a positive influence on purchase intention. Meanwhile the mediation testing demonstrates the brand image partially facilitates the relationship between e-WOM and purchase intention.
\end{abstract}

Keywords: e-WOM, brand image, purchase intention

\section{INTRODUCTION}

The rise of various brands of smartphone products entering the Indonesian market offers a wide selection of brands to consumers in the country. No fewer than 15 brands of smartphones circulating and even there are 10 most selling brands Indonesia (http://www.harianjogja.com/baca/2016/06/15/penjualan-smartphone-ini-10-merekponsel-grossing-in-Indonesia-729087). In these circumstances, there are numerous determinants that can create self-purchase intention of consumers towards a product brand. If consumers do not have enough knowledge on a product and are faced with plenty of brands of the products, consumers then will search for information in making buying decision. The decision which proceeds to the act of buying is a behaviour and intention first becomes the trigger of the behaviour to happen (Ajzen, 1991; Bemmaor, 1995; Albarracín et al, 2001; Hsiao and Morwitz, 2002; Morwitz and Fitzsimons, 2004; Chandon and Reinartz, 2004a; Morwitz, 2012). The personal buying intention arising within the consumer becomes the key factor for the consumer to decide prior to their action of purchasing (Morrison, 1979). Therefore, it is essential for mobile phone companies to recognise the key factors that can generate consumers' purchase intentions in the era of competitiveness between brands of smartphones. Some previous studies (Sundaram et al., 1998; Bansal and Voyer, 2000; Sweeney, et al., 2008; Xia and Bechwati 2008; Trusov et al., 2009; Khan et al., 2015) explain that the word-of-mouth plays a significant role in influencing consumers to form their intention to buy. The more 
vigorous and positive word-of-mouth about a brand, the more likely purchase intention are shaped within the consumer themselves (Bristor, 1990). The development of Information technological era simplifies and accelerates an individual or groups to access information from various sources such as social media. When a person utilises the Internet to seek information about a product through social media and receive a positive or negative opinion / negative from other people about a brand product that is being considered, it can be said that word-ofmouth is happening online. Since word-of-mouth occurs in an Internet media then it transforms itself in the era of information technology into electronic word-of-mouth (e-WOM). Several earlier studies (Park et al., 2007; Park and Lee, 2008; Atika etal., 2012; Fan and Miao, 2012; Bataineh, 2015) explain that $e-W O M$ strongly influences the purchase intention.

In addition, brand image along with e-WOW also contributes to shaping a person's purchase intention as mentioned by Wang and Tsai (2014), Wu et al. (2011 and Tulipa (2015) in their research that the brand image influences the purchase intention of a person. Brand image is the accumulative result of consumers' perceptions who are satisfied with a consistent performance of a type of product being in long term use. As a result, this leads to one of the consequences of consumer satisfaction that is the emergence of word-of-mouth/e-WOM. The more a brand gets positive testimonials ( $e-W O M$ positive), the more increasingly it will be positive brand image. Therefore it has been proven that $e$-WOM affects the brand image, and brand image itself forms influence in the purchase intention (Zarei and Kazemi, 2014; Jalilvand and Samiei, 2012; Torlak et al., 2014; Shahrinaz et al., 2016). Hence, there is a close relationship between these three variables but only fewer research observed to have examined the role of brand image as a mediatory variable of the relationship between $e$-WOM and purchase intention.

As the capital of Papua province, Jayapura City, for smartphone marketers becomes one barometer town in Eastern Indonesia in relation to the use of information technology through the internet. It is not a surprise that smartphone nowadays has been one of the most utilised devices for accessing information over the Internet since the smartphone has embedded a variety of social media applications (Facebook, Twitter, WhatsApp, Instagram, WeChat and more). Online daily newspaper, CNN-Indonesia, reported that there had been a significant increase in the utilisation the Internet in Eastern Indonesia which was contemplated from 1 hour use per day by 35.5\% (https://www.cnnindonesia.com/teknologi/20150414194905185-46662/melongok-demografi-pengguna-internet-di-indonesia-timur/). Meanwhile, the Samsung smartphone had been the most widely used brand in Indonesia since 2015 to 2016 (see Table 1). The result was obtained based on the survey conducted by Frontier Consulting Group. 
Table 1.

Top Brand Award Smartphone Category 2013-2016

\begin{tabular}{|c|c|c|c|c|c|c|c|}
\hline \multirow{11}{*}{ 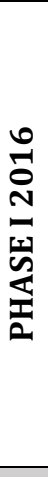 } & Brand & TBI & TOP & \multirow{11}{*}{ 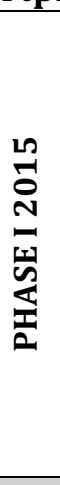 } & Brand & TBI & TOP \\
\hline & Samsung & $43.4 \%$ & TOP & & Samsung & $29.7 \%$ & TOP \\
\hline & Nokia & $10.9 \%$ & TOP & & Blackberry & $24.7 \%$ & TOP \\
\hline & Blackberry & $9,8 \%$ & & & Nokia & $16.7 \%$ & TOP \\
\hline & iPhone & $5.8 \%$ & & & iPhone & $4.5 \%$ & \\
\hline & Smartfren & $5.4 \%$ & & & Smartfren & $3.8 \%$ & \\
\hline & Lenovo & $4.0 \%$ & & & Cross & $3.0 \%$ & \\
\hline & Oppo & $3.4 \%$ & & & Advan & $2.9 \%$ & \\
\hline & Asus & $3,2 \%$ & & & Mito & $2.5 \%$ & \\
\hline & & & & & Lenovo & $2.4 \%$ & \\
\hline & & & & & Oppo & $2.2 \%$ & \\
\hline & & & & & & & \\
\hline \multirow{7}{*}{ 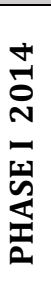 } & Blackberry & $44.3 \%$ & TOP & \multirow{7}{*}{ 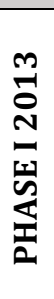 } & Blackberry & $39.0 \%$ & TOP \\
\hline & Nokia & $22.7 \%$ & TOP & & Nokia & $37.0 \%$ & TOP \\
\hline & Samsung & $18,0 \%$ & TOP & & Samsung & $11.1 \%$ & TOP \\
\hline & iPhone & $4.3 \%$ & & & Nexian & $3.6 \%$ & \\
\hline & Sony Ericsson & $3.3 \%$ & & & IPhone & $2.0 \%$ & \\
\hline & Nexian & $2.2 \%$ & & & Cross & $1.9 \%$ & \\
\hline & Cross & $1.6 \%$ & & & & & \\
\hline
\end{tabular}

Source: Top Brand Award (2013-2016). Top Brand Index (TBI) to be above $10 \%$ then in the category TOP Brand

It appears from table 1 that Samsung smartphone ranked first from 2015 to 2016. If inspected more carefully it is seen that the Samsung smartphone escalated significantly from 2013 until 2016. The increase of Samsung smartphone brand image correlates with the rise of testimony (e-WOM) in online media (http://tekno.liputan6.com/read/3040647/review-samsung-galaxys8-smartphone-terbaik-di-year-this). Therefore, this research aims to analyse the effect of $e$ WOM and brand image concerning purchase intention of smartphone brand Samsung. This study also examines the role of brand image variable which facilitates the relationship between $e$-WOM and purchase intention.

\section{e-WOM}

\section{LITERATURE REVIEW}

E-WOM has changed profoundly the way information is disseminated throughout the world since the rapid growth of information technology and this way leaves the traditional marketing media and communication behind (Laroche et. Al., 2005). According to Dellarocas et al. (2007), reviews, feedbacks, and opinions with regards to a brand of products attained via the Internet (online) are such valuable information for consumers and companies. Study conducted by Lee et al., (2011) shows that $e$-WOM influences consumer behaviour towards a purchase decision. Information made by consumers are very helpful in making decision to purchase cause the occurrence of the intention to buy. A number of studies (Ba and Pavlou, 2002; Clemons et al., 2006; Chevalier and Mayzlin, 2006; Park and Lee, 2009) who studied that consumers who give ideas or opinions to others will create a positive brand image raise purchase intention.

\section{Brand Image}

Brand image, according to Aaker (1991), is a set of assets and liabilities associated with the brand that is the name, the symbol that can increase or decrease a value assigned by the corporates/ consumers of the product or the value given by the overall consumers against products offered by the company.

Brand image comprises attributes and benefits associated with the brand that make the brand typical so that it can be distinguished from other brands (Webster and Keller, 2004). To see the 
equity of a brand then Keller (1993) developed the concept of customer-based brand consisting of two dimensions, brand and brand awareness. Wu et al. (2011) stated that the brand image present positive effect on the purchase intention. Peter and Olson (2009) stated that the brand image incorporate the knowledge and belief (cognitive) to the brand attribute, the consequences of the brand use and state of consumption, such as the evaluation of the feelings and emotions (affective response) associated with the brand.

Brand image is a set of beliefs and ideas as well as consumer experience against certain brands. Therefore, buyers' attitude and behaviour towards the brand are strongly determined by a brand image involving several components, namely physical attributes (product model and specifications) and the benefits/ performance of the product (the value of the product perceived by consumers related to product functionality to meeting the needs and desires).

\section{Purchase Intention}

Schiffman and Kanuk (2009) states that after the value of a product is confirmed by consumers, so the proportion of consumers' purchase intentions depends on the benefits and value obtained. The larger the purchase intention is, the more increasingly the likelihood of a purchase action to occur. Therefore, purchase intention is often used as a reflection of the actual purchasing behaviour. Purchase intention plays a role in purchase planning at the stage of future buying decision. According to Blackwell et al. (2001), the desire for a product thought by shoppers is defined as purchase intentions. Therefore, prior to the act of purchasing proper products that meet their needs and desires, the consumers will undertake research in advance to identifying a desired product, and also looking for information about the product, evaluating, purchase action and feedback.

\section{Hypotheses}

Based on the background and the literature review, this study postulates the following research hypothesis.

H1: $e-W O M$ has a positive influence on purchase intention

H2: $e$-WOM has a positive influence on brand image

H3: Brand image has a positive effect on purchase intention

H4: Brand image mediates the relationship of e-WOM with purchase intentions

\section{Research Model}

Picture 1. Research Model

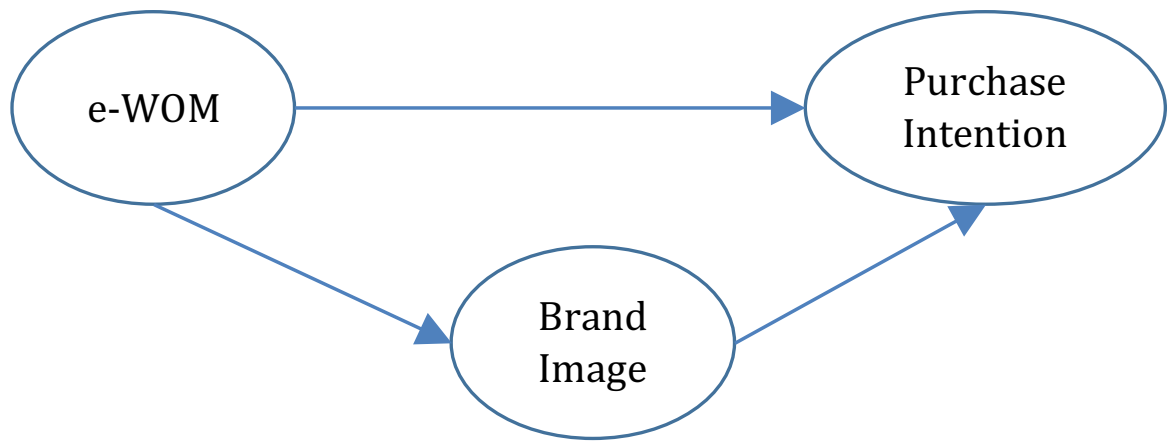

Source: the model was adopted from Jalivand and Samiei (2012)

\section{Research method}

In this study, the quantitative approach with deduction method and causal hypothesis testing employed as well as a survey design to obtain primary data obtained from questionnaires. Respondents in this study are university students who shop and utilise smartphones in 
Jayapura city. Prior to the distribution of questionnaires, the researchers visited several universities in Jayapura city and conducted an earlier short interview with students to ensure that the respondents of the research are those consumers who have used and is operating smartphones also have a frequent Internet access. The unit of analysis is an individual. The time dimension of the study is a cross-sectional (Sekaran, 2013). The reasons for selecting college students in Jayapura city as the site of the research sample since college students consist of different backgrounds, races and beliefs so that the place are appropriate location of the sample in order to meet the condition of various samples to representing the population although the sample frame is not known. Sampling is done through a nonprobability sampling with purposive sampling technique by judgment sampling. Sample criteria is the consumers (smartphone users) of brand Samsung on their own initiatives and own money without orders or coercion from others and often access information through the internet. Rules of thumb are used in determining the sample size of 100 respondents. According to Hair et al. (2006), the sample size of more than 30 to 500 most appropriate in general studies. It is also stated that the sample size to do factor analysis is of 5 to 10 times the number of items of questions in the questionnaire. Furthermore, there are twelve questions used in this study, so the sample size of 100 respondents have been sufficient. Scale such as Likert seven points for each question with a score of answers to each item is (1) Strongly Disagree, (2) Disagree, (3) Somewhat Disagree (4) Neutral, (5) Somewhat Agree (6) Agree , (7) Strongly Agree.

Testing the validity of this research was conducted through Confirmatory Factor Analysis (CFA) for the items were adopted from previous research questions with modifications. Before the CFA test was executed researchers did the Kaiser Meyer Olkin (KMO) and Bartiett's tests intended to examine the correlation between variables. However, coefficient Cronbach's Alpha was employed to test the reliability of research instrument with the alpha value is above 0.6 (Hair et al., 2006). Data analysis in this study uses multiple regression analysis and hierarchical regression analysis. Mathematically, the regression equation is shown as follows:

$$
\begin{gathered}
\mathrm{BI}=\mathrm{A}+\beta 1 \mathrm{e}-\mathrm{WOM}+\mathrm{e} \\
\mathrm{NB}=\propto+\beta 1 \mathrm{e}-\mathrm{WOM}+\beta 2 \mathrm{BI}+\mathrm{e}
\end{gathered}
$$

\section{Description}

$\mathrm{BI}=$ Brand Image

$\mathrm{NB}=$ Purchase Intention

$\mathrm{e}-\mathrm{WOM}=$ electronic Word of Mouth

$\propto=$ Intercept

$\beta=$ Constant

$\mathrm{e}=$ error terms

In the meantime, mediatory testing refers to the model developed by Baron and Kenny (1986). The steps taken to test mediation as follows:

a. Performing the direct relationship test between the independent variable(e-WOM) with the dependent variable (purchase intention)

b. Performing the direct relationship test between the independent variable $(e-W O M)$ and brand image variable.

c. Testing the effect of independent and mediatory variables together on the dependent variable (purchase intention). 
Based on these measures the regression equation to test mediation as follows:

$$
\begin{gathered}
\mathrm{NB}=\propto+\beta 1 \mathrm{e}-\mathrm{WOM}+\mathrm{e} \\
\mathrm{BI}=\propto+\beta 1 \mathrm{e}-\mathrm{WOM}+\mathrm{e} \\
\mathrm{NB}=\propto+\beta 1 \mathrm{e}-\mathrm{WOM}+\beta 2 \mathrm{BI}+\mathrm{e}
\end{gathered}
$$

Based on these steps brand image variable plays a mediatory role if the following conditions are met:

a. $e$-WOM variable has a significant effect directly on brand image.

b. $e$-WOM variable has a significant effect directly on purchase intention.

c. Brand image variable has a significant effect directly on purchase intention.

d. Complete mediating effect (complete mediation) is proved when the $e$-WOM variable does not explain the variation in purchase intention, however, only the brand image variable does.

e. Full mediating effect (full mediation) is proved if the early variable of $e$-WOM showing a significant effect on purchase intention becomes insignificant when the variable $e$-WOM and brand image are simultaneously regressed on the variable of purchase intention.

f. Partial mediating effect (partial mediation) will occur if significance of the e-WOM variable declines towards purchase intention when the brand image variable is regressed together with the $e$-WOM variable.

\section{RESULTS OF RESEARCH INSTRUMENTS TEST}

Final result of research instrument by means of CFA analysis found that the value of KMO and Bartllet's tests (see Table 2) showed a value of 0,836 (above 0.50 ) and also for the rotated component matrix it is found that from all items of the questions, only question number one of the brand image variable (BI1) should be dropped and not be used since loading on different indicators. Hence, after the item was dropped it results in only eleven items of questions that passed the test of construct validity (convergent and discriminant validity) - (see table 3 ).

\begin{tabular}{|c|c|c|}
\hline \multicolumn{2}{|c|}{$\begin{array}{l}\text { Kaiser-Meyer-Olkin Measure of Sampling } \\
\text { Adequacy. }\end{array}$} & .836 \\
\hline Bartlett's Test of & Approx. Chi-Square & $\begin{array}{l}585 \\
314\end{array}$ \\
\hline Sphericity & $\mathrm{df}$ & 55 \\
\hline & Sig. & .000 \\
\hline
\end{tabular}

Table 2. KMO and Bartlett's Tests KMO and Bartlett's Test 
Table 3.

Rotated Component Matrix ${ }^{a}$

\begin{tabular}{|l|l|l|l|}
\hline \multirow{2}{*}{} & \multicolumn{3}{|c|}{ Component } \\
\cline { 2 - 4 } & 1 & 2 & \multicolumn{1}{c|}{3} \\
\hline eWOM1 & .753 & & \\
eWOM2 & .863 & & \\
eWOM3 & .711 & & \\
eWOM4 & .779 & & \\
eWOM5 & .769 & & .605 \\
BI2 & & & .905 \\
BI3 & & & .801 \\
BI4 & & & \\
NB1 & & .875 & \\
NB2 & & .838 & \\
NB3 & & .872 & \\
\hline
\end{tabular}

Extraction Method: Principal

Component Analysis.

Rotation Method: Varimax with

Kaiser Normalization. ${ }^{\text {a }}$

a. Rotation converged in 5 iterations.

Meanwhile, the results of Cronbach's Alpha reliability test it can be seen in Table 4 below that the alpha value of indicator of each variable has a value above 0.60 . It indicates that all items of the questionnaire is reliable.

Table 4

Test of Reliability

\begin{tabular}{|l|c|c|}
\hline \multicolumn{1}{|c|}{ Variabel } & $\begin{array}{c}\text { Cronbach's } \\
\text { Alpha }\end{array}$ & $\begin{array}{c}\mathrm{N} \text { of } \\
\text { Items }\end{array}$ \\
\hline e-WOM & .873 & 5 \\
\hline Brand Image & .767 & 3 \\
\hline $\begin{array}{l}\text { Purchase } \\
\text { Intention }\end{array}$ & .883 & 3 \\
\hline
\end{tabular}

\section{Results of Hypothesis Test}

The purpose of testing the hypotheses 1 to 4 is to check the role of each variable. Its results are shown respectively in Tables 5, 6, 7, and 8 below. For stage of hypothesis 4 testing (test of mediation), it is not required to do first and second steps but only steps three for the during the data analysis it has followed the hypothesis 1 to hypothesis 3 (having the same stages).

Table 5

Test of Hypothesis 1

Coefficients ${ }^{a}$

\begin{tabular}{|c|c|c|c|c|c|}
\hline \multirow[t]{2}{*}{ Model } & \multicolumn{2}{|c|}{$\begin{array}{c}\text { Unstandardized } \\
\text { Coefficients }\end{array}$} & $\begin{array}{c}\text { Standardized } \\
\text { Coefficients }\end{array}$ & \multirow[t]{2}{*}{$\mathrm{t}$} & \multirow[t]{2}{*}{ Sig. } \\
\hline & $\mathrm{B}$ & Std. Error & Beta & & \\
\hline (Constant) & 3.816 & 1.412 & & 2.704 & .008 \\
\hline e-WOM & .282 & .056 & .452 & 5.015 & .000 \\
\hline
\end{tabular}

a. Dependent Variable: NB 
From the first hypothesis testing by simple regression analysis with a significance level of $5 \%$ $(0.05)$ as presented in Table 5 demonstrates that $e$-WOM give a substantial effect $0.000<$ 0.005 ) to purchase intentions.

Table 6

Test of Hypothesis 2

Coefficients ${ }^{\mathrm{a}}$

\begin{tabular}{|c|c|c|c|c|c|}
\hline \multirow[t]{2}{*}{ Model } & \multicolumn{2}{|c|}{$\begin{array}{l}\text { Unstandardized } \\
\text { Coefficients }\end{array}$} & $\begin{array}{l}\text { Standardized } \\
\text { Coefficients }\end{array}$ & \multirow[t]{2}{*}{$\mathrm{t}$} & \multirow[t]{2}{*}{ Sig. } \\
\hline & B & Std. Error & Beta & & \\
\hline (Constant) & 7.265 & 1.070 & & 6.789 & .000 \\
\hline e-WOM & .252 & .043 & .512 & 5.908 & .000 \\
\hline
\end{tabular}

a. Dependent Variable: BI

The test of second hypothesis using simple regression analysis with a significance level of $5 \%$ $(0.05)$ as shown in Table 6 proves that $e$-WOM affects significantly $(0.000<0.005)$ on the brand image.

Table 7

Hypothesis 3

Coefficients ${ }^{\mathrm{a}}$

\begin{tabular}{|c|c|c|c|c|c|}
\hline \multirow[t]{2}{*}{ Model } & \multicolumn{2}{|c|}{$\begin{array}{l}\text { Unstandardized } \\
\text { Coefficients }\end{array}$} & $\begin{array}{c}\text { Standardized } \\
\text { Coefficients }\end{array}$ & \multirow[t]{2}{*}{$\mathrm{t}$} & \multirow[t]{2}{*}{ Sig. } \\
\hline & B & Std. Error & Beta & & \\
\hline (Constant) & 3.855 & 1.617 & & 2.384 & .019 \\
\hline $\mathrm{BI}$ & .508 & .118 & .400 & 4.320 & .000 \\
\hline
\end{tabular}

a. Dependent Variable: NB

Furthermore, the hypothesis 3 test using simple regression analysis with a significance level of $5 \%(0.05)$ as illustrated in Table 7 shows beyond doubt that the brand image has a significant effect $(0.000<0.005)$ on purchase intentions.

Table 8

Hypothesis 4

Coefficients $^{\mathrm{a}}$

\begin{tabular}{|c|c|c|c|c|c|c|c|}
\hline \multirow[t]{2}{*}{ Model } & \multicolumn{2}{|c|}{$\begin{array}{l}\text { Unstandardized } \\
\text { Coefficients }\end{array}$} & $\begin{array}{l}\text { Standardized } \\
\text { Coefficients }\end{array}$ & \multirow[t]{2}{*}{$\mathrm{t}$} & \multirow[t]{2}{*}{ Sig. } & \multicolumn{2}{|c|}{$\begin{array}{l}\text { Collinearity } \\
\text { Statistics }\end{array}$} \\
\hline & B & Std. Error & Beta & & & Tolerance & VIF \\
\hline (Constant) & 1.709 & 1.678 & & 1.019 & .311 & & \\
\hline 1 e-WOM & .209 & .064 & .335 & 3.254 & .002 & .737 & 1.356 \\
\hline BI & .290 & .131 & .228 & 2.220 & .029 & .737 & 1.356 \\
\hline
\end{tabular}

a. Dependent Variable: NB

Results of combined regression test between the independent and mediatory variables demonstrated in Table 8, found that there is a significant effect e-WOM $(0.002<0.05)$ on purchase intention. This indicates that e-WOM can directly affect purchase intention and brand image. It is clearly described in table 5 that the value of significance of e-WOM variable towards purchase intention which was originally 0,000 then weakened or declined in Table 8 be 0.002 when being regressed together with the brand image to purchase intention. This verifies that 
the variable of mediation (brand image) partly mediates the relationship between $e$-WOM with the buying intention.

\section{DISCUSSION}

Based on the results of hypothesis testing it is identified that hypotheses 1 to 4 are supported. This has claimed that the brand of smartphone, Samsung, has a positive brand image amongst the students in Jayapura. Meanwhile, it is also the most reviewed smartphone brand in different online social media. This leads to the impact on consumers'/ college students' purchase intentions in the city of Jayapura to arise. Besides, the results of a brief interview with the majority of students also proves that although there are many different brands of mobile phones traded in shops, it is true to claim that in the process of making purchase decision of the devices students are more reliant on information obtained from various testimonies spread over the internet through social media such as Facebook, Twitter, Instagram and other social media. The study reveals that $e-W O M$ positively affects buyers on purchase intention, therefore, this study confirms the results of research conducted by Wang and Tsai (2014), Shahrinaz et al. (2016), Bataineh (2015). The study also proved that the brand image has a positive influence on purchase intention. The result of this research reinforces previous research (Aaker, 1991; Webster and Keller, 2004; Keller, 1993; Wu et al., 2011; Peter andOlson, 2009) which describe the relationship between brand image and a person's buying intention. Samsung smartphone is evidenced to have a positive impression thus the purchase intention increases within the student in Jayapura city. This means the better brand image is, the higher purchase intention are created (Jalilvand and Samiei, 2012). Additionally, this study indicates the occurrence of partial mediation of the relationship between e-WOM and intention to buy after the brand image acts as a variable of mediation. However, when looking back at the results of analysis it shows a decrease in value which is not very significant. This may be due to the current era of technology, e-WOM can form and change the brand image very quickly, and also consumers sometimes no longer see the brand image of a product because of numerous reviews, online positive opinions. Furthermore, this investigation proves that the brand image of a product/ company can be formed from countless reviews both positive and negative about the brand. Therefore, if there is more positive $e$-WOM created about the brand of Samsung smartphone it will then increase the positivity of brand image of the device and it certainly leads to greater creation of purchase intention towards Samsung smartphone

\section{MANAGERIAL IMPLICATION}

Samsung firm Ltd. (PT. Samsung) needs to improve product quality their smartphone and also enhance service quality in sales activity as this will form a positive $e$-WOM amongst users of the gadgets. Furthermore, this corporation must also continue to make innovations and improvements for their products because it will establish a brand image. It is not easy to build a brand image in the extreme competition of smartphone production and marketing in Indonesia as in the era of Internet technology today brand image may be created in a relatively quick period of time. In addition to this, brand image is the accumulation of positive/ negative perceptions shaped during the time when consumers to utilise a product brand. As a result consumers may feel the failure of product performance of a brand that will not be difficult to provide their reviews and opinion on online social media.

\section{SUGGESTIONS AND LIMITATIONS OF THE RESEARCH}

This research is limited to the type of consumers (university students) who are users of Samsung smartphone in the city of Jayapura. Future research need to find antecedent that makes up the e-WOM so that the models developed will be comprehensive. Furthermore, the scope of research needs to be expanded, not only in capital of Papua province, Jayapura, but also in other cities in Eastern Indonesia. 
Ivana, W., \& Uturestantix. (2018). Does Brand Image Certainly Mediate Relationships between e-WOM and Purchase Intention? A Case Study of Samsung Smartphone Marketing in Papua. Advances in Social Sciences Research Journal, 5(3) 567-577.

\section{References}

Ajzen, I. (1991), "The Theory of Planned Behavior". Organizational Behavior and Human Decision Processes 50, $179-211$.

Aaker, D.A. (1991), "Managing Brand Equity: Capitalizing on the Value of a Brand Name". The Free Press, New York, NY.

Albarracín et al. (2001), "Theories of Reasoned Action and Planned Behavior as Models of Condom Use: A MetaAnalysis". Psychological Bulletin 127(1), 142-161.

Atika et al., (2012), "The Effect of Electronic Word of Mouth, Message Source Credibility, Information Quality on Brand Image and Purchase Intention". Ekuitas: Jurnal Ekonomi dan Keuangan, 94-108.

Ba, S. and Pavlou, P.A. (2002), "Evidences of the Effect of Trust in Electronic Markets: Price Premiums and Buyer Behaviour". MIS Quarterly, Vol. 26, No. 3, pp. 243-267.

Bansal, H.S., and Voyer, P.A. (2000), "Word-of-Mouth Processes Within a Service Purchase Context". Journal of Service Research, 3(2), 166-177.

Bataineh Abdallah Q. (2015), "The Impact of Perceived e-WOM on Purchase Intention: The Mediating Role of Corporate Image". International Journal of Marketing Studies, Vol. 7, No. 1, 126-137.

Bemmaor, A. C. (1995), "Predicting Behavior From Intention-To-Buy Measures: The Parametric Case”. Journal of Marketing Research 32, 176-191.

Blackwell, R., Miniard, P., \& Engel, J. (2001), “Consumer Behaviour”. 9th ed., Ohio: South-Western.

Bristor, J. M., (1990), "Enhances Explanations of Word of Mouth Communications: The Power of Relationships," Research in Consumer Behavior, 4, 51-83.

Chandon, P. V. G. M. and W. J. Reinartz (2004a), "Do Intentions Really Predict Behavior? Self-Generated Validity Effects in Survey Research". Journal of Marketing Research 69(2), 1-14.

Chevalier, J.A. and Mayzlin, D (2006), "The Effect of Word of Mouth on Sales: Online Book Reviews". Journal of Marketing Research, Vol. 43, pp. 345-354.

Clemons, E.K., et al., (2006), "When Online Review Meets Hyper Differentiation: A Study of the Craft Beer Industry". Journal of Management Information Systems, Vol. 23, No. 2, pp. 149-171.

Dellarcos, C., et al., (2007), "Exploring the Value of Online Product Reviews in Forecasting Sales: The Case of Motion Picture". Journal of Interactive Marketing, Vol. 21, No. 4, pp. 23-45.

Fan Yi-Wen and Miao Yi-Feng (2012), "Effect of Electronic Word-of-Mouth on Consumer Purchase Intention: The Perspective of Gende Differences". International Journal of Electronic Business Management, Vol. 10, No. 3, 175181.

Hsiao, C. B. S. and V. G. Morwitz (2002), "The Role of Stated Intentions in New Product Purchase Forecasting". Advances in Econometrics 16, 11-28.

Jalilvand M. R. and Samiei N., (2012), "The Effect of Electronic Word of Mouth on Brand Image and Purchase Intention. An Empirical Study in the Automobile Industry in Iran". Marketing Intelligence \& Planning, Vol. 30, No. 4, 460-476.

Keller, K.L. (1993), “Conceptualizing, Measuring, and Managing Customer-Based Brand Equity”. Journal of Marketing, 57, (1), 1-22.

Khan S. A., et al., (2015), "Impact of Word of Mouth On Consumer Purchase Intetion". Sci. Int. (Lahore), 27(1), 479482.

Laroche, M., et al., (2005), "Internet versus Bricks-and Mortar Retailers: An Investigation into Intangibility and its Consequences". Journal of Retailing, Vol. 81, No. 4, pp. 251-267.

Lee, D., et al., (2011), "The Impact of Online Brand Community Type on Consumer's Community Engagement Behaviors: Consumer-Created Vs. Marketer-Created Online Brand Community in Online Social-Networking Web Sites". Cyberpsychology Behavior and Social Networking, Vol. 14, No. 1, pp. 59-63.

Morrison Donald G. (1979), "Purchase Intention and Purchase Behavior”. Journal of Marketing, Vol. 43, No. 2, 6574.

Morwitz V. (2012), “Consumers' Purchase Intention and Their Behavior” Foundationand Trends® Marketing Vol. 7, No. 3, 181-230. 
Morwitz, V. G. and G. J. Fitzsimons (2004), “The Mere Measurement Effect: Why Does Measuring Intentions Change Actual Behavior?". Journal of Consumer Psychology 14(1-2), 64-74.

Park, D.H., et al. (2007), “The Effects of On-line Consumer Reviews on Consumer Purchasing Intention: The Moderating Role of Involvement". International Journal of Electronic Commerce, 11(4), 125-148.

Park, D.H., \& Lee, J. (2008), "eWOM Overload and Its Effect on Consumer Behavioral Intention Depending on Consumer Involvement". Electronic Commerce Research and Applications, 7, 386-398.

Park, D. H. and Lee, J. (2009), "eWOM Overload and Its Effect on Consumer Behavioral Intention Depending on Consumer Involvement". Electronic Commerce Research and Applications, Vol. 7, No. 4, pp. 386-398.

Peter, J.P. and Olson, J. (2009), “Consumer Behavior”. 9th edition, Mc-Graw Hill.

Schiffman, L.G. dan Kanuk, L. L. (2009) “Consumer Behavior”. 10th ed, Englewood Cliffs, New Jersey: Prentice-Hall. Shahrinaz Irwan et al. (2016), "Relationship and Impact of e-WOM and Brand Image towards Purchase Intention of Smartphone?". Journal of Scientific Research and Development, Vol. 3(5), 117-124.

Sundaram, D.S., et al., (1998), Word-of -Mouth Communications ; a Motivational Analysis". Advances in Consumer Research, 25, 527-531.

Sweeney, J. C., et al. (2008), "Factors Influencing Word of Mouth Effectiveness: Receiver Perspectives". European Journal of Marketing, 42 (3/4), 344-364.

Torlak Omer et al., (2014), "The Effect of Electronic Word of Mouth on Brand Image and Purchase Intention: An Application Concerning Cell Phone Brands for Youth Consumers in Turkey", Journal of Marketing Development and Competitiveness, Vol. 8(2), 61-68.

Trusov, M., et al. (2009), "Effects of Word-of-Mouth Versus Traditional Marketing: Findings From an Internet Social Networking Site”. Journal of Marketing, Vol. 73 No. 5, 90-102.

Tulipa Diyah (2015), "The Country of Origin and Brand Image Effect on Purchase Intention of Smartphone in Surabaya-Indonesia". Mediterranean Journal of Social Sciences. Vol. 6, No. 5, 64-70.

Wang Ya-Hui dan Tsai Cing-Fen (2014), "The Relationship Between Brand Image and Purchase Intention: Evidence From Award Winning Mutual Funds". The International Journal of Business and Finance Research, Vol. 8 , No. 2, 27-40.

Webster, F.E. and Keller, K.L. (2004), “A roadmap for branding in industrial markets”. Brand Management, Vol. 11 No. 5, pp. 388-402.

Wu Paul C. S., et al., (2011), "The Effect of Store Image and Service Quality on Brand Image and Purchase Intention for Private Label Brands". Australian Marketing Journal, Vol. 19, 30-39.

Xia, L. and Bechwati, N.N. (2008), "Word of Mouth: The Role of Cognitive Personalization in Online Consumer Reviews". Journal of Interactive Advertising, Vol. 9 No. 1, 108-28.

Zarei Azim dan Kazemi Ahmad (2014), “The Impact of Positive Word-of-mouth on Store Brand Purchase Intention with Mediated Effect of Store Image and Perceived Risk towards SBs", Journal Accounting and Marketing, Vol. 3(1), 1-6.

(http://www.harianjogja.com/baca/2016/06/15/penjualan-smartphone-ini-10-merek-ponsel-terlaris-di-indonesia729087) 